\title{
That Noble Dream: Analysis of the "Objectivity" Question of the Historiography of Ranke
}

\author{
Xianchuan Chen \\ School of Politics and Law, Sichuan University of Arts and Science, Dazhou, China \\ Email: cxc0826@126.com
}

How to cite this paper: Chen, X. C. (2020). That Noble Dream: Analysis of the "Objectivity" Question of the Historiography of Ranke. Advances in Historical Studies, 9, 92-97.

https://doi.org/10.4236/ahs.2020.93008

Received: July 20, 2020

Accepted: August 30, 2020

Published: September 2, 2020

Copyright (c) 2020 by author(s) and Scientific Research Publishing Inc. This work is licensed under the Creative Commons Attribution International License (CC BY 4.0).

http://creativecommons.org/licenses/by/4.0/

\begin{abstract}
In the 19th century, the German historian Leopold von Ranke integrated scientific methods and attitudes into history and put forward the historical theory of "objectivism", which made history free from the shackles of traditional religion and political propaganda and became an independent discipline. However, questioned by later scholars, Ranke's opinion has been described as a "noble dream" given that the absolute "objectivity" can hardly be achieved in history. In fact, Ranke's quest for history goes far beyond simply and objectively describing the superficial facts, but rather seeks to find some connections and spirits behind the facts of history. This quest goes beyond "pure facts" per se, but it must be based on objective truth.
\end{abstract}

\section{Keywords}

Historiography of Ranke, Objectivity Question, That Noble Dream

\section{Introduction}

The difference between professional historical research and non-professional historical narrative lies in the fact that the former has a higher level of validity, that is, "objectivity" (Jorn Rusen, 2010). The famous German historian Leopold von Ranke revealed that history is only "the presentation of the facts" and emphasized "objectivity", which made history independent from theology, philosophy, literature and art, and gradually led to the trend of professionalization of history. The standard of "objectivity" makes historians with specialized academic training claim to be different from non-professional historians with moral education or propaganda aims. At the same time, the criterion of "objectivity" once became a sacred belief in the professionalization of history. In spite of some challenges and doubts it faces, "objectivity" is still an inescapable criterion in the minds of many scholars today. 
The American scholar Peter Novick had made a systematic and rigorous analysis of the historical concept of "objectivity" in his book That Noble Dream: The "Objectivity Question" and the American Historical Profession. The discussion about "objectivity" has been going on in the West for a long time, and it has never stopped from the time of Ranke to the present day. In different times, "Objectivity" has faced different challenges in different times. After leading the development of history for a considerable period of time, it faces the coexistence of supporters and skeptics for a long time. No matter what attitude we hold towards "objectivity" today, we cannot deny that this topic is still worth discussing.

\section{Discussion}

\subsection{Ranke's Historiography and the Crowning of "Objectivity"}

Ranke's historical conception is quite different from that of his predecessors, and "objectivity" can be said to be aimed at them in a certain sense. In the first half of the 19th century, many western historians adopted the concept of "enlightenment history" or "educational history", believing that history should play a role in "enlightening" the times, preach morality and ethics and serve the goals of education (Jorn Rusen, 2010). Ranke opposed the notion of "enlightenment history" or "educational history", and the "use of history" by older historians, he emphasizing the "objectivity" of history. "Objectivity" requires historians to eliminate personal bias and take a neutral attitude to describe history. "Faithfulness to the past facts and the truth that coincide with the past facts" (Peter Novick, 2009). In this sense, history is only a mirror of past facts, or a mock model. Rank is widely quoted as saying, "History has always been regarded to have the function of judging the past, teaching the present, and benefits the future. For such a heavy responsibility, this book dares not yearn for. It merely shows the true nature of things (Es will bloss zeigen, wie es eigentlich gewesen)." "Showing the true nature of things", that is, what we usually call Rank's principle of "wie es eigentlich gewesen", which has become one of the foundations of Rank's historiography.

Although there are many doubts as to whether unconditionally "objective" is possible, Ranke does adhere to this principle in his own historiographical practice. According to Rank, "objectivity" in historical narrative lies first and foremost with the historian that is, historians must not hold personal prejudice, interests and religious preference. As Peter Novick sums it up, "the sharp distinction between the perceiver and the perceived, the facts and values, especially the history and fiction." A historian, "being a historian, one must renounce any allegiance to anything other than history. Historians can only express the highest loyalty to the 'objective historical facts'." What historians should do is to enter into materials and historical facts without any preconceptions, and let the facts speak for themselves (Peter Novick, 2009). What historians should do is not to determine right and wrong, but to "tell the truth". Ranke himself was a Luthe- 
ran, but still managed to be impartial about the contradictory history between Catholicism and Protestantism when he wrote the book Histoire des papes. Such impartiality would not be possible without that loyalty to "objectivity" and a detached attitude.

Ranke's idea of "objectivity" has deeply influenced the development of history all over the world. The revised historiography of Ranke eventually takes a leading position in the history circles and is highly held up as the "authentic" of historiography. Although there are some subtle but significant differences between "objectivity" emphasized by later historians and Ranke's original idea. Since the 19th century, the concept of "science" has become a truth in the field of natural science, and it has quickly permeated through the field of history, which contributes to the influential "science history". Historians have had a long discussion about whether history is "science". However, behind this problem, or even the cause for this problem lies the concept of "science" has the controlling voice. In the discourse context of that time, only the historiography claims to be "objectivity" can be in tune with "science" and be recognized and accepted. Therefore, it is easy to understand that the "objectivity" advocated by Ranke became the choice of the times and the mainstream trend of thought after revision.

\section{2. "What Can't Be Done": Query on "Objectivity"}

"Objectivity" has been questioned and challenged from a variety of sources. For example, Foucault, the representative of postmodernism, once proposed "temporal history", which means that historical consciousness is inevitably limited by the views and interpretation of the times, some historical facts are fictional and there is no self-contained and constant state from a specific perspective which constantly changes in time and space. Therefore, the constant "fact" rooted in "objectivity" has also been denied. In Collingwood's words, "every present possesses its own past, and any imaginary reconstruction of the past is aimed at reconstructing the present". This kind of "present consciousness" is opposed to the detached "objectivity" (Huang, 2008).

Derrida's conception of "text" also has a strong impact on "objectivity". According to Derrida's famous saying, "There is nothing outside the text", history can only look inside the text, and there is no real world to consult. Historical research does not have an objective past to rely on other than residual texts. In this way, the history built on documents is bound to become a fictitious symbol game, which is a mere word trick (Huang, 2008).

Peter Novick also points out that there are some conflicts and confusion in the topic of "objectivity". He argues that it is "unfair, untruth and misleading" to make" the distortion of the historical narrative because of ideological assumptions and aims" in opposition to "the idea that historians should be free of such influences" (Peter Novick, 2009). It is true that ideology may cause a lack of "objectivity", but does it certainly cause a lack of "objectivity"? Should ideology be swept away as an extremely dangerous thing? Would that solve the problem? 
It may still be difficult to get obvious answers to the above questions. George Bancroft's historical works have been criticized for writing history from a "democratic point of view". In response to this criticism, he said: "If there is democracy in history, it is not subjective, but the objectivity they called here." (Peter Novick, 2009). It indeed reminds us that we should reflect on our resolute attitude in dealing with ideology and values.

These denials of "objectivity" from different theoretical and cognitive perspectives may be said to be a matter of opinion and it is hard to come to a conclusion. But on one can deny another doubt, that is, "historical objectivity" cannot be fully achieved. Ranke has stated, "I once put forward an ideal, and people would tell me that it was unattainable. But the reality tells us that a man's mind can be infinite, but he is inherently limited in what he can achieve." (Jorn Rusen, 2010). It can be seen that while Ranke believes that the principle of objectivity should be uphold, he also knows that it is an unattainable ideal. It is impossible for the historian to forget themselves or completely get rid of the influence of values. Even the most rigorously trained historian can't break the constraints of his own time, cultural thinking, knowledge, etc., to make an absolute "objective" narrative, if such "objective" exists at all. Therefore, the pursuit of "objectivity" has become an "impossible task". Opponents therefore deride it as "that noble dream" which is unreachable or "like nailing jelly to a wall" Those who support it, even Ranke himself, see it as a guiding ideal, a "myth": a "myth" that historians are unencumbered by values.

Although the tone of those who call "objectivity" a "noble dream" is full of sarcasm, the metaphor itself does reveal a major defect in the principle of "objectivity". The quest for "objectivity" has indeed been a great guide for historians, and makes history truly become an independent discipline with fruitful achievements. But on the other hand, such "objectivity" is difficult to achieve, which is only a distant "dream". This has not been satisfactorily accepted by many people. Not everyone can agree that "objectivity" should be embraced with the attitude of "though unachievable, aspiration to it remains." as that of Ranke. This leads to such a problem: to pursue "objectivity" is to pursue a "dream"; what would history look like if "objectivity" were abandoned? It may be difficult to exist, or it may revert to being a tool for possession or entertainment.

Just as the supporters of "science history" can't deny that "objectivity" is an "impossibility", the opponents can't deny that this "impossibility" can play and has played a very important role and has the value of existence. It should be noted that "objectivity of history" is important in establishing and maintaining the professional history discipline. If the history discipline loses such a "myth", it will also lose its foundation and authority, just as the postmodernists declared-"history is dead." In fact, the myth of "historical objectivity" plays a normative role in ensuring and enhancing academic justice, which guaranteeing the validity of academic "ritual" (Peter Novick, 2009). For example, under this principle, historians must "purge presuppositions from their minds", "enter history empty-handed". Historian should strictly abide by the procedure of analyzing 
and researching historical data, and use archives carefully. Only under the principle of "objectivity" can historians arrive at the only historical truth on the platform of "facts" when they disagree with each other. On some specific issues, it may be difficult to reach "objective facts" as claimed by "historians of science". But this does not negate the quest for objective history. As Peter Novick said: "It is better not to claim to be against an idea simply because it lacks consistency." (Peter Novick, 2009).

\subsection{The Search for Meaning beyond "Objectivity"}

"Objectivity" seems to be an inherent rejection of value judgment. To complete an "objective" historical narrative, one must first abandon the value orientation of historians. Value is regarded as a bias, and even if it claims to have universal and fair value orientation (which they don't), it cannot cast off the prejudice of the times. Therefore, value orientation is considered to be an obstacle to the "objectivity" of justice. Indeed, we can't deny the fact that history has been distorted under the narration of historians with national feelings, moral ethics and theoretical presupposition. When "objectivity" is coined, it is directed against those historical narratives that "exploit history" to achieve specific goals. However, it is still necessary for us to put aside what we already know for a moment and take a new look at this question: should we pit the two against each other and eradicate value in history as value orientation may impair the objectivity of history?

If one is a propagandist of moral and ethics, he may cite historical stories for educational purpose. If one is a philosopher, he may as well use history as an argument to support philosophical views. If one is a historian, there is no doubt that he must adhere to the objectivity of history. No objective historical facts, no history. But is it the ultimate pursuit of historians to make an "objective" account of history?

In fact, there is a misunderstanding of Ranke's historical thought that is widespread. "Objectivity" is the cornerstone of Ranke's historiography, but not the whole content of it. Ranke emphasized that there is a deeper concern than "pure facts", namely the belief that "facts" have "spiritual content". The "spirit" to which Rank refers may be related to the will of God, just as when he emphasizes that each era has its own independent value and when he emphasizes "description of individuality", based on the fact that each era is directly related to God and each era is equal before God. For Ranke, the true "facts" is the sum of the external "pure facts" and the "things happening inside". Ranke is against the "historical facts" describing "superficial" facts, arguing that the purpose of history is not merely to search for individual facts, but to understand how the facts relate to each other and the meaning of the whole facts (Huang, 2008).

Many of those posterity, such as the Ranke School and the New Ranke School, only chose the front half for their own needs when they emphasized Ranke's "objectivity". That Ranke request historians to go deep into the "essence" and find meaning has been selectively ignored. 
In fact, it's not just Ranke who believes that after extracting "pure facts", one should continue to look for "spiritual content" and understand the relationship between facts and the meaning of the facts as a whole. Ranke's predecessor Humboldt has reminded that historians who stay on the superficial of facts will miss the truth inherent in history. Individual facts can be obtained by textual research of historical materials, while it is only by relying on "intuition" that we can discover the relationship and meaning of the historical connotation. It should be noted that the imagination of historians must be constrained by the "facts", and cannot be fabricated. Liang Qichao, a descendant of Ranke, who lived far away in Eastern China, also have the same understanding. Liang said, "The purpose of history is to attach new meaning or new value to the true facts of the past, so that modern people can learn from it. Then explain this purpose in detail. One cannot talk about meaning without true facts, and cannot talk about value without the meaning. Only get meaning and value can he move to activity." (Liang, 2000). Although their interests may not be necessarily similar, they all emphasize that there should be a deeper exploration than the mere enumeration of facts. At the same time, it is still need to emphasize that this must be based on facts.

\section{Conclusion}

This "noble dream" can be more practical if it can find the compromise between theoreticality and practicality. It is completely abandoned only because absolute "objectivity" is difficult to achieve, which seems to be too harsh. Although it is hard for historians to describe history objectively, they should not be limited to describing individual historical facts, but also explore the deep connection and spirit of various facts on this basis. This is different from using philosophy or theoretical presupposition to interpret history. For if there are some connection and spirit behind the historical facts, this is merely giving an account of "objective", just "telling the truth of the matter".

\section{Conflicts of Interest}

The author declares no conflicts of interest regarding the publication of this paper.

\section{References}

Huang, X. J. (2008). Postmodernism and Historiography (p. 22, p. 97, p. 98, p. 137, pp. 138-124). Beijing: SDX Joint Publishing Company.

Liang, Q. C. (2000). Methodology in the Study of Chinese History (p. 123). Shijiazhuang: Hebei Education Press.

Novick, P. (2009). That Noble Dream (p.2, p. 5, p. 9, p. 8, p. 33). Beijing: SDX Joint Publishing Company.

Rusen, J. (2010). Series of Ideas of History; Leopold von Ranke. Über die Epochen der neueren Geschichte (p. 10, p. 13). Beijing: Peking University Press. 